\title{
Frequency of osteopenia and osteoporosis in men and women living with HIV/Aids: an observational study
}

\author{
Frequência de osteopenia e osteoporose em homens e mulheres vivendo com \\ HIV/Aids: um estudo observacional
}

Bruno Augusto Aguilar ${ }^{1}$ (D), André Pereira dos Santos² (D), Dalmo Roberto Lopes Machado ${ }^{1,2}$ (D), Euripedes Barsanulfo Gonçalves Gomide ${ }^{2}$ (D), Emerson Sebastião ${ }^{3}$ (D), Anderson Marliere Navarro ${ }^{4}$ (D)

\begin{abstract}
Aims: To identify the frequency in changes of bone metabolism, including below the average value for age, osteopenia, and osteoporosis, in people living with HIV/AIDS (PLWHA) and to compare the frequency of factors associated with bone mineral density (BMD) and body composition between sex. Methods: This observational study assessed 106 PLWHA (65 male) recruited from the University Hospital of Ribeirão Preto Medical School from 2013 to 2014 . BMD was measured using Dual Energy X-ray Absorptiometry (DXA). Standard deviation values for Z- and T-score proposed by the International Society for Clinical Densitometry were adopted to classify participants below the average value for age, osteopenia, and osteoporosis. Qui-square and Fischer's exact tests were employed to compare males and females based on their factors associated with BMD reduction. Results: Fifty-two (49\%) PLWHA presented at least one diagnosis for below the average value for age, osteopenia, and osteoporosis, being $37(57 \%)$ and $15(37 \%)$ male and female, respectively. Frequency of alcohol consumption was higher in males $(n=20 ; 30.8 \%)$ than females $(n=05 ; 12.2 \%)(p=0.028)$. Conclusions: A high rate of PLWHA showed changes in bone metabolism, with a higher frequency in males. The frequency of alcohol consumption was higher in males, and it may partially explain the possible causes of the increased rates of bone metabolism changes observed in this group. This information may help develop strategies for reducing the frequency of diagnosis for below the average value for age, osteopenia, osteoporosis improving quality of life in PLWHA.
\end{abstract}

Keywords: HIV; Bone Density; Highly Active Antiretroviral Therapy; Prevalence; Diagnosis.

\begin{abstract}
RESUMO
Objetivos: Identificar a frequência de alterações no metabolismo ósseo, incluindo valores abaixo do estimado para idade, osteopenia e osteoporose, em pessoas vivendo com HIV/Aids (PVHA) e comparar a frequência de fatores associados à redução da densidade mineral óssea (DMO) e composição corporal entre sexos. Métodos: Estudo observacional que avaliou 106 PVHA (65 do sexo masculino) recrutadas do Hospital das Clínicas da Faculdade de Medicina de Ribeirão Preto da Universidade de São Paulo entre os anos 2013 e 2014. A DMO foi medida utilizando a Absorciometria Radiológica de Dupla Energia (DXA). Valores de desvio padrão Z- e T- scores propostos pela Sociedade Internacional para Densitometria Clínica foram adotados para classificar os participantes em abaixo do valor estimado para idade, osteopenia e osteoporose. Os testes do qui-quadrado e exato de Fischer foram empregados na comparação entre os sexos baseado em seus respectivos fatores associados à redução da densidade mineral óssea. Resultados: Cinquenta e dois (49\%) PVHA apresentaram ao menos um diagnóstico para abaixo do valor estimado para idade, osteopenia e osteoporose, sendo 37 ( $57 \%$ ) do sexo masculino e 15 (37\%) feminino. A frequência de consumo de álcool foi maior no sexo masculino $(n=20 ; 30,8 \%)$ comparado ao feminino $(n=5 ; 12,2 \%)(p=0,028)$. Conclusões: Uma alta taxa de PVHA apresentaram alterações no metabolismo ósseo, com maior frequência no sexo masculino. A frequência no consumo de álcool foi maior no sexo masculino, podendo explicar parcialmente as possíveis causas para taxa aumentada de alterações no metabolismo ósseo observada nesse grupo. Essa informação pode contribuir no desenvolvimento de estratégias para redução da frequência do diagnóstico para valores abaixo do estimado para idade, osteopenia e osteoporose, melhorando a qualidade de vida em PVHA.
\end{abstract}

Palavras-chave: HIV; Densidade Óssea; Terapia Antirretroviral de Alta Atividade; Prevalência; Diagnóstico.

\footnotetext{
School of Physical Education and Sport of Ribeirao Preto at the University of Sao Paulo at Ribeirao Preto (SP), Brazil.

College of Nursing of the University of Sao Paulo at Ribeirao Preto (SP), Brazil.

Department of Kinesiology and Physical Education, Northern Illinois University, Dekalb, Illinois, United States of America.

Department of Clinical Medicine, Ribeirao Preto Medical School, University of Sao Paulo, Ribeirao Preto (SP), Brazil.
} 


\section{INTRODUCTION}

Access to free of cost antiretroviral therapy (CART) in Brazil has contributed to reducing the number of deaths due to complications associated with Human Immunodeficiency Virus (HIV) ${ }^{1,2}$. The availability and access to such therapy treatment have positively impacted life expectancy in people living with HIV/AIDS (PLWHA). In fact, life expectancy in PLWHA has increased 37 additional years ${ }^{3}$. This creates a new challenging scenario where PLWHA are aging with HIV infection. PLWHA may be at higher risk for comorbidities due to prolonged use of CART and the aging process. For instance, there is evidence of the high prevalence of comorbidities in this population, including a reduction in bone mineral density (BMD) ${ }^{4}$. Changes in bone metabolism in PLWHA are multifactorial. The frequency of factors associated with BMD reduction includes sex, advanced age, time of HIV diagnosis, high viral load, decrease in CD4+ T cell count, time of exposure to CART, use of tobacco and frequency of alcoholic drinks, and low physical activity level ${ }^{5,6}$. In terms of the antiretroviral classes from CART associated-BMD reduction, the protease inhibitors (PIs) are specially highlighted?

BMD reduction is associated with an increased frequency of skeletal diseases, including osteopenia and osteoporosis. Osteoporosis is a systemic skeletal disease characterized by reduced BMD values and microarchitecture deterioration in bone tissue, with consequent increases in bone fragility and fracture susceptibility $^{8}$. Osteopenia refers to a bone condition in which calcification, density or mass is reduced, but it is not reduced enough to be classified as osteoporosis ${ }^{9}$. Studies indicate that the prevalence of osteoporosis is three times higher in PLWHA compared to people without the condition ${ }^{10}$. The high susceptibility for fractures due to osteoporosis may negatively impact the quality of life in PLWHA, and increase the need for health care services; increasing the public costs in the health sector.

The University Hospital of the School of Medicine of the University of Sao Paulo in Ribeirão Preto, Brazil (HC-FMRP/USP) is an institution maintained by the State of São Paulo. In 2014, the Special Unit for Treatment of Infectious Diseases (UETDI) from the HC-FMRP/USP provided medical services for nearly 1,300 PLWHA. To the best of our knowledge, there are no recent studies that investigated the frequency of changes in bone metabolism in PLWHA at HC-FMRP/USP. In addition, there is limited data on rates of change in bone metabolism in this population. This is important because identifying PLWHA affected by changes in bone metabolism associated with a reduction in BMD, especially osteopenia and osteoporosis, implies opportunities for improving prevention, treatment, distribution of resources, and reduction of hospitalization cost, contributing to a better quality of life in this population. Further, understanding the differences in body composition between male and female sex, considering the frequency of factors associated with sex-specific BMD reduction may indicate ways for preventing skeletal diseases. To this end, this study sought to identify the frequency in changes of bone metabolism, including below the expected range for age, osteopenia, and osteoporosis, in PLWHA and to compare the frequency of factors associated with BMD reduction and body composition among sex.

\section{MATERIALS AND METHODS}

\section{Study population}

We conducted a cross-sectional observational study design and assessed 106 individuals. All patients had a diagnosis of HIV/AIDS and were receiving treatment at the HC-FMRP/USP/UETDI at the time of the study (between November 2013 and November 2014). The research team set up a study booth next to the waiting room of the hospital. All PLWHA $(n=125)$ waiting for an appointment with a health care professional during the days of our data collection were invited to participate in the study. Inclusion criteria included: a) diagnosis of HIV/AIDS as adults; b) aged 18 years and over; c) currently under CART treatment. Exclusion criteria included: a) being treated for opportunistic diseases or cancer; b) immune inflammatory diseases; c) wasting syndrome; d) rare metabolic disorders; e) being pregnant; f) using a prosthesis and being amputated and; g) being engaged in an exercise program in the past six months, or experiencing rapid weight loss in the past six months. A total of 19 PLWHA (male $=10$ and female $=9$ ) were considered not eligible. The reasons included, declined to the study (5), diagnosed 
with HIV/AIDS under 18 years (2), in treatment for cancer (2), pregnant (1), use of prosthesis (3), engaged in regular exercise program (3), rapid body weight loss in the last six months (1), and not completed all study steps (2). Thus, data were collected in $106(84.8 \%)$ patients. To achieve a power range of 0.75 to 0.80 with a significance level of $p<0.05$ for detecting differences among sex, a sample size of 100 to 112 PLWHA was recommended.

\section{Ethical Aspects}

The study's protocol was approved by the University Hospital, School of Medicine of the University of São Paulo in Ribeirão Preto, Brazil (Ethical Review Board; process number: 7082/2011) and was in agreement with the Helsinki declaration. All participants volunteered to participate in the study and signed an informed consent prior to data collection.

\section{Procedures}

Participants' medical records were used to collect information on age (years), time of HIV diagnosis (years since the diagnosis), time of exposure to CART (years since the beginning of treatment), and type of CART (with or without protease inhibitor). In addition, participants complete a questionnaire on race/ethnicity, tobacco, illicit drugs, and frequency of alcohol consumption (yes $\geq 3$ units per day). The self-reported race/ethnicity of the participants was assessed following the definitions by the Brazilian Institute of Geography and Statistics ${ }^{11}$.

\section{Laboratory exams}

The clinical condition of PLWHA was verified by viral load and the CD4+ T lymphocyte count. The laboratory exams were performed at the Laboratory of Viral Load, Serology Sector of HC-FMRP/USP. Viral load level is detectable when HIV RNA is $>40 \mathrm{~mL}-1$ copies. Viral load was determined by the Real Time Abbott method using the Siemens - Versant $\circledast$ HIV - 1 RNA 3.0 kit and DNA Analyzer System 340@. CD4+ T lymphocyte count (cells $/ \mathrm{mm}^{3}$ ) was performed by Flow
Cytometry, using the Multitest ${ }^{\circledR}$ kit and the Calibur ${ }^{\circledR}$ Facs cytometer (Becton Dickinson - São José CA).

\section{Body composition assessment and osteopenia and osteoporosis diagnosis by DXA}

Body composition and changes in bone metabolism including below the expected range for age, osteopenia and osteoporosis were assessed using a DXA equipment (DXA Hologic instrument model QDR 4500W); which is a valid, non-invasive and accurate measure. A trained technician operated the equipment following standard procedures $^{12}$. Total body weight $(\mathrm{kg})$, total trunk fat mass $(\mathrm{kg})$, lower limbs fat mass $(\mathrm{kg})$, and bone mineral content (BMC) $(\mathrm{kg})$ were measured for sample characterization. BMD $\left(\mathrm{g} / \mathrm{cm}^{2}\right)$ was measured at the lumbar spine, right hip, and left forearm for identifying bone alterations. For classifying below the expected range for age, osteopenia, and osteoporosis, we adopted the values of standard deviation for Z- and T-score proposed by the International Society for Clinical Densitometry ${ }^{13}$.

\section{Statistical Analysis}

Exploratory analyses were conducted to investigate potential outliers. Descriptive analysis (i.e., measures of central tendency, standard deviation (SD) and $95 \%$ confidence interval $(95 \% \mathrm{CI})$ ) were used for sample characterization separated by sex. Parametric statistics were used considering the central limit theorem ${ }^{14}$. We further used an independent $t$ test to examine potential differences between males and females based on their body composition metrics assessed by DXA. The chi-square test was employed to assess differences among sex for uses of tobacco, frequency of alcoholic drinks, and frequency of bone metabolism alterations. Fisher's exact test was used to assess differences between sex for uses of illicit drugs, and regions of bone metabolism alterations. Absolute $(n)$ and relative (\%) values were depicted for frequency of osteopenia and osteoporosis by sex. Analyses were performed using the SPSS 23 (IBM Corporation, Armory, N.Y), with the level of significance set at $\mathrm{p}<0.05$. 


\section{RESULTS}

Results about the average age of the participants, self-reported race/ethnicity, time of diagnosis of HIV, time of exposure to CART, type o CART, $\mathrm{CD} 4+\mathrm{T}$ lymphocytes, and viral load account were previously described ${ }^{15}$. Briefly, we observed homogeneity of participants among age, time of diagnosis of HIV, time of exposure to cART treatment, $\mathrm{CD} 4+\mathrm{T}$ lymphocytes, and viral load account (no one PLWHA showed detectable viral load) ${ }^{15}$. Detailed information on body composition measured by DXA separated by sex is provided in Table 1 . About body composition, we did not observe a significant difference by sex only for BMD.

In terms of variables that may be influence bone alterations, only frequency of alcoholic drinks was higher in male than female sex $(p=0.028$; male $\mathrm{n}=20 / 30.8 \%$ and female $\mathrm{n}=05 / 12.2 \%$ ). We did not observe differences by sex for uses of tobacco $(\mathrm{p}=0.478$; male $\mathrm{n}=20 / 30.8 \%$ and female $n=10 / 24.4 \%)$, and uses of illicit drugs $(\mathrm{p}=0.157$; male $\mathrm{n}=04 / 6.2 \%$ and female $\mathrm{n}=01 /$ $4.1 \%)$.
Figure 1 shows the frequency and absolute values of PLWHA with bone alterations. Fifty-two (49\%) out of 106 PLWHA showed bone metabolism alterations. According to sex, 15 (37\%) females showed at least one bone metabolism alterations compared to 37 (57\%) males. The chi-square test showed association among males and bone metabolism alterations $\left(X^{2}=7,658 ; p<0,006\right)$.

Figure 2 shows the frequency and absolute values of PLWHA with bone alterations at the lumbar spine, right hip, and left forearm. At the lumbar spine region, 13 (\%) PLWHA showed below the expected range for age, 23 (\%) osteopenia, and eight $(\%)$ osteoporosis. At the right rip region, a three (\%) PLWHA showed below the expected range for age, $20(\%)$ osteopenia, and two (\%) osteoporosis. At the left forearm region, eight (\%) PLWHA showed below the expected range for age, 15 (\%) osteopenia, and nine (\%) osteoporosis. Fisher's exact test showed that there is no association between sex and changes in bone metabolism at the lumbar spine region $\left(X^{2}=5,894 ; p=0,112\right)$, right rip region $\left(X^{2}=2,062 ; p=0,628\right)$, and left forearm region $\left(X^{2}=7,497 ; p=0,053\right)$.

\section{Table 1}

Mean and standard deviation values separated by sex of body composition metrics assessed by DXA in people living with HIV/AIDS.

\begin{tabular}{|c|c|c|c|c|c|}
\hline \multirow{3}{*}{ Variables } & \multicolumn{4}{|c|}{ People living with HIV/AIDS $(n=106)$} & \multirow{3}{*}{ t (p) value } \\
\hline & \multicolumn{2}{|c|}{ Male $(n=65)$} & \multicolumn{2}{|c|}{ Female $(n=41)$} & \\
\hline & Mean \pm SD & $95 \% \mathrm{CI}$ & Mean \pm SD & $95 \% \mathrm{CI}$ & \\
\hline \multicolumn{6}{|l|}{ Body composition by DXA } \\
\hline Total body weight (kg) & $70.7 \pm 11.5$ & 67.8 to 73.4 & $63.6 \pm 11.6$ & 59.7 to 67.1 & $3.0(0.003)$ \\
\hline Total trunk fat mass $(\mathrm{kg})$ & $26.0 \pm 6.3$ & 24.4 to 27.5 & $33.8 \pm 7.0$ & 31.4 to 35.9 & $\begin{array}{l}-5.8 \\
(<0.001)\end{array}$ \\
\hline Total limb fat mass $(\mathrm{kg})$ & $5.2 \pm 2.3$ & 4.6 to 5.8 & $8.1 \pm 3.6$ & 7.0 to 9.2 & $\begin{array}{l}-4.9 \\
(<0.001)\end{array}$ \\
\hline Total bone mineral content $(\mathrm{kg})$ & $22.3 \pm 3.5$ & 21.3 to 23.2 & $18.3 \pm 3.6$ & 17.3 to 19.3 & $\begin{array}{l}5.6 \\
(<0.001)\end{array}$ \\
\hline Bone mineral density $\left(\mathrm{g} / \mathrm{cm}^{2}\right)$ & $1.1 \pm 0.1$ & 1.1 to 1.1 & $1.1 \pm 0.1$ & 1.0 to 1.1 & $2.0(0.053)$ \\
\hline
\end{tabular}

Note: HIV: Human Immunodeficiency virus; AIDS: Acquired immunodeficiency syndrome; SD: Standard deviation; 95\% CI: Confidence interval in 95\%; mm: millimeters; DXA: Dual energy x-ray absorptiometry; Kg: Kilograms; g/ $\mathrm{cm}^{2}$ : grams per square centimeters. 


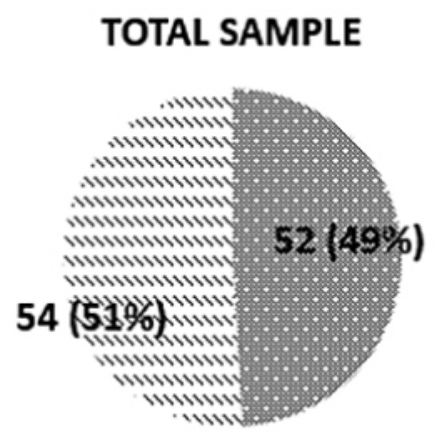

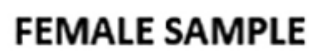

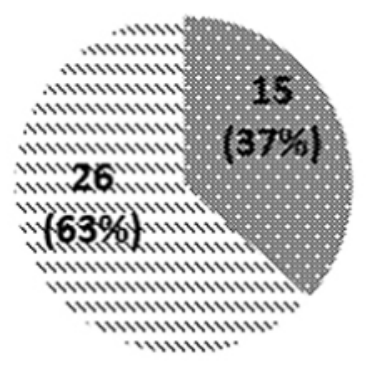

MALE SAMPLE

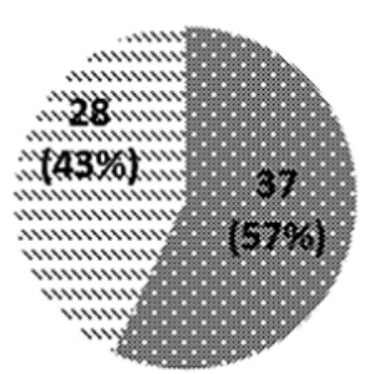

變 Signal of bone metabolism alterations

N No Signal of bone metabolism alterations

Figure 1: Frequency and absolute values of people living with HIVIAIDS with bone alterations: total sample, female sample and male sample.

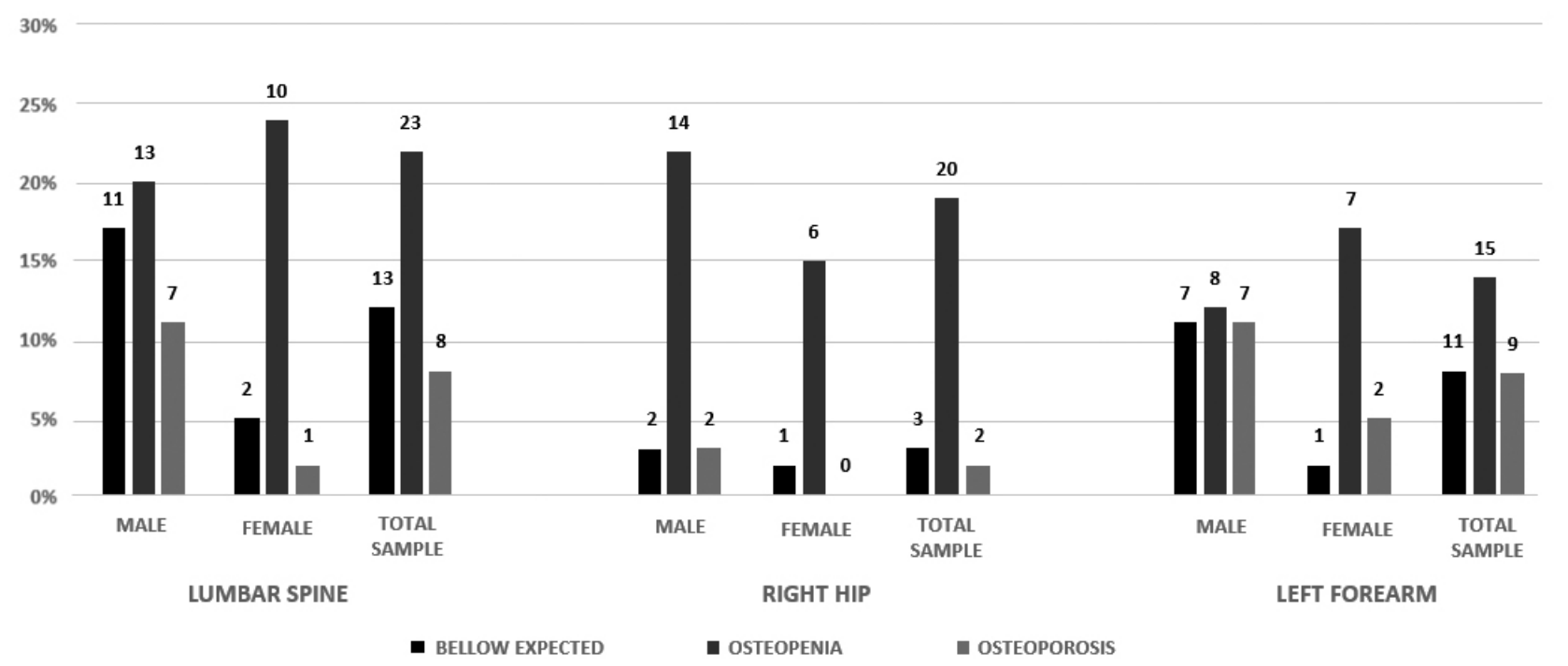

Figure 2: Frequency and absolute values for the lumbar spine, right rip and left forearm alterations in people living with HIVIAIDS.

\section{DISCUSSION}

This study sought to verify the frequency of osteopenia and osteoporosis in PLWHA receiving treatment at the HC-FMRP/USP and to compare the frequency of factors associated with BMD reduction and body composition between sex. The findings indicated high rates of changes in bone metabolism in PLWHA (half of PLWHA present reduction in BMD indicating diagnosis for clinical diseases development) with males being more frequent compared to their female counterparts. When we compared the variables that may influence bone alterations, males showed higher frequency of alcoholic drinks than females. Our findings are important and may be used by health professionals involved in the care of HIV/AIDS patients by proposing strategies of prevention and treatment for bone alterations, contributing to a better quality of life in this population.

Bone demineralization occurs naturally in both males and females during the aging process, and starts during the third decade of life, with increased velocity for women post menopause ${ }^{16}$. Beyond the frequency of factors associated with BMD reduction in PLWHA, bone demineralization is potentiated by HIV infection and the use of CART ${ }^{17}$. Thus, it is common to observe a higher frequency of changes in bone metabolism in PLWHA than seronegatives (people without the condition) ${ }^{10,18}$. According to the literature, the frequency of factors associated with 
bone mineral demineralization in PLWHA include: sex, advanced age, time of HIV diagnosis, high viral load, reduction in CD4 $+\mathrm{T}$ cell count, time of exposure to CART, use of tobacco and frequency of alcoholic drinks, and low level of physical activity ${ }^{5,6}$. In previous results we did not observe significant differences between sex for age, CD4 + T cell count, time of HIV diagnosis, and time of exposure to $\mathrm{CART}^{14}$. These results indicate the homogeneity of the sample and suggest no different influences of these frequencies of factors by sex.

We observed that the mean time of HIV diagnosis was relatively high in both $\operatorname{sex}^{14}$. A longitudinal study evaluated BMD reduction and identified that low values of BMD are associated with long time of HIV diagnosis ${ }^{19}$. In fact, a review conducted by Borderi et.al. concluded that bone tissue can be understood as a reservoir of HIV, once the effects of antiretroviral treatment are limited on this tissue as a result of a limited blood flow, infecting osteoblasts and leading to an incomplete filling of the bone gaps during remodeling, with a consequent reduction in $\mathrm{BMD}^{20}$. Of note, all participants in our study were under CART. There is evidence suggesting that some classes of cART, especially PIs contribute to accelerating bone demineralization, which is associated with increased frequency of osteoporosis and risk of fractures in PLWHA $7,21,22$. However, we did not observe differences between sex in "time of exposure to CART" and use of PIs ${ }^{15}$.

The trunk fat mass and total limb fat mass were higher in the female sex. Some studies suggest that body fat in pre and postmenopausal women has a strong association with BMD, being a protective factor against decreasing bone demineralization ${ }^{23-25}$. It is clear in the literature that estrogen hormones play a role in bone tissue homeostasis, and the decrease in its levels in postmenopausal women leads to bone loss and osteoporosis ${ }^{26,27}$. Nevertheless, these hormones can be produced by adipose tissue exerting a role in bone metabolism in postmenopausal obese women ${ }^{28}$. Further, obese postmenopausal female subjects present with a reduction in the concentration of sex hormone-binding globulin, leading to an increase in metabolically active estrogens (both factors that promote bone remodeling), preventing BMD loss (29-31). In terms of bone mineral content (BMC), although a significant difference was observed, in which males presented with higher BMC than females, this can be partially explained by the fact that males had a greater average height when than females. Even with no differences in BMD between sex comparisons, we expected higher values for males than females due to the male's height and the strong association between BMC and BMD (32).

Another difference observed refers to frequency of alcohol consumption, in which males presented with higher frequency of alcohol consumption than females. Previous studies conducted with seronegative individuals observed a strong association between high alcohol consumption and changes in bone metabolism; suggesting high alcohol consumption as a risk factor for BMD reduction ${ }^{33-35}$. Song et al. (2018) observed an increase in BMD after alcohol abstinence in seronegative males ${ }^{6}$. The literature indicates that alcohol abuse is associated with a net loss in bone mass, decreasing osteoblast activity $^{36}$.

Regarding the frequency of changes in bone metabolism among PLWHA, our findings are similar to those observed in national and international studies. For instance, a cross-sectional study, conducted in France with 492 PLWHA with a mean age of 43 years, also observed a high frequency of osteoporosis (53.7\%) and osteopenia $(26.8 \%)^{5}$. In another study, conducted at the University Hospital of Lille, France, with 49 males with an average age of 36 years, $25 \%$ had reduced BMD values and were diagnosed for clinical disorders (below the expected range for age, osteopenia or osteoporosis). In addition, the lumbar spine was the region most affected, similar to our study ${ }^{37}$. A national study conducted at the University of São Paulo in São Paulo, Brazil with 108 PLWHA observed that $23.15 \%$ presented with reduced $B M D$ values ${ }^{38}$.

The findings of our study should be interpreted with caution due to some limitations. We did not measure or control for participants eating habits, physical activity and the use of other medication (other than CART) that could potentially affect BMD. Though the difference found in alcohol consumption between sexes, this variable was not evaluated by the standardized survey. Some important data was not evaluated, as a correlation between treatment time and the probability to develop bone changes, viral load, race, etc. New research approaches considering these variables may help 
health professionals understand the particular influences for bone metabolism alterations in PLWHA and thus to promote strategy for avoiding and or minimizing this occurrence. Despite the limitations, we were able to engender valuable information that may contribute to the devise allocation of financial resources by the public sector, regarding the prevention and treatment of changes in bone metabolism in PLWHA; contributing to increase quality of life of this population. Our sample size represents about $10 \%$ of all PVHA being treated at HC-FMRPUSP / UETDI. Even we did not evaluate a large number of PVHA, our results indicate a good view of the scenario, highlighting important characteristics for the body composition status of this population in this hospital. Studies that consider local characteristics of the reality of PLWHA treated in hospitals and health centers are necessary to identify the burden of the frequency of factors associated with BMD reduction. This is important to mitigate the impact of comorbidities associated with HIV and reduce the public health system costs.

\section{CONCLUSION}

Even though PLWHA from both sexes did not have differences in BMD, males showed the highest frequency of alterations in bone metabolism. Only the frequency of use of alcoholic drinks may suggest the possible causes for the increased rates of bone metabolism changes observed in males. This information may help develop strategies for resources' allocation and behavior change awareness for reducing the frequency of diagnosis for below the expected range for age, osteopenia, osteoporosis, and improve quality of life in PLWHA.

\section{REFERENCES}

1. Dourado I, Veras MAdS, Barreira D, Brito AMd. Tendências da epidemia de Aids no Brasil após a terapia anti-retroviral. Rev Saúde Pública. 2006;40:9-17.

2. Malta M, Da Silva CM, Magnanini MM, Wirtz AL, Perissé $A R$, Beyrer $C$, et al. Improvement of HAART in Brazil, 1998-2008: a nationwide assessment of survival times after AIDS diagnosis among men who have sex with men. BMC public health. 2015;15(1):226.

3. Teeraananchai S, Kerr S, Amin J, Ruxrungtham K, Law M. Life expectancy of HIV-positive people after starting combination antiretroviral therapy: a meta-analysis. HIV Med. 2017;18(4):256-66.
4. Serrão R, Piñero $C$, Velez J, Coutinho $D$, Maltez F, Lino $S$, et al. Non-AIDS-related comorbidities in people living with HIV-1 aged 50 years and older: The AGING POSITIVE study. Int J Infect Dis. 2019;79:94-100.

5. Cazanave C, Dupon M, Lavignolle-Aurillac V, Barthe N, Lawson-Ayayi S, Mehsen N, et al. Reduced bone mineral density in HIV-infected patients: prevalence and associated factors. Aids. 2008;22(3):395-402.

6. Song T-H, Shim J-C, Jung D-U, Moon J-J, Jeon D-W, Kim S-J, et al. Increased Bone Mineral Density after Abstinence in Male Patients with Alcohol Dependence. Clin Psychopharmacol Neurosci. 2018;16(3):282.

7. Fernandez-Rivera J, Garcia R, Lozano F, Macias J, GarciaGarcia J, Mira J, et al. Relationship between low bone mineral density and highly active antiretroviral therapy including protease inhibitors in HIV-infected patients. HIV Clin Trials. 2003;4(5):337-46.

8. Consensus A. Consensus development conference: diagnosis, prophylaxis, and treatment of osteoporosis. Am J Med. 1993;94(6):646-50.

9. Thacker $\mathrm{HL}$, Richmond $\mathrm{B}$. In rebuttal: osteopenia is a useful diagnosis. Cleve Clin J Med. 2006;73(1):34.

10. Brown TT, Qaqish RB. Antiretroviral therapy and the prevalence of osteopenia and osteoporosis: a meta-analytic review. Aids. 2006;20(17):2165-74.

11. Petruccelli JL, Saboia AL. Características étnico-raciais da população: classificações e identidades: Instituto Brasileiro de Geografia e Estatística--IBGE; 2013.

12. Ramos RL, Armán JA, Galeano NA, Hernández AM, Gómez JG, Molinero JG. Dual energy X-ray absorptimetry: fundamentals, methodology, and clinical applications. Radiología (English Edition). 2012;54(5):410-23.

13. 2019 ISCD Official Positions - Adult ISCD.org2019 [updated August 20, 2019. Available from: https://www.iscd. org/official-positions/2019-iscd-official-positions-adult/.

14. Bolfarine H. Elementos de amostragem: Blucher; 2005.

15. Dos Santos AP, Navarro AM, Schwingel A, Alves TC, Abdalla PP, Venturini ACR, et al. Lipodystrophy diagnosis in people living with HIV/AIDS: prediction and validation of sex-specific anthropometric models. BMC public health. 2018;18(1):806.

16. Farr JN, Khosla S. Skeletal changes through the lifespan-from growth to senescence. Nat Rev Endocrinol. $2015 ; 11(9): 513$.

17. Yoshino Y, Koga I, Misu K, Seo K, Kitazawa T, Ota Y. Prevalence of Bone Loss and the Short-Term Effect of Anti-retroviral Therapy on Bone Mineral Density in Treatment-Naïve Male Japanese Patients with HIV. Open AIDS J. 2019;13(1).

18. Loiseau-Peres $S$, Delaunay $C$, Poupon $S$, Lespessailles $E$, Ballouche N, Arsac $P$, et al. Osteopenia in patients infected by the human immunodeficiency virus. A case control study. Joint Bone Spine. 2002;69(5):482-5.

19. Bonjoch A, Figueras M, Estany C, Perez-Alvarez N, Rosales J, del Rio $L$, et al. High prevalence of and progression to low bone mineral density in HIVinfected patients: a longitudinal cohort study. Aids. 2010;24(18):2827-33.

20. Borderi M, Gibellini D, Vescini F, De Crignis E, Cimatti L, Biagetti $C$, et al. Metabolic bone disease in HIV infection. Aids. 2009;23(11):1297-310.

21. Tebas P, Powderly WG, Claxton S, Marin D, Tantisiriwat $W$, Teitelbaum SL, et al. Accelerated bone mineral loss in HIV-infected patients receiving potent antiretroviral therapy. AIDS (London, England). 2000;14(4):F63.

22. Madeddu G, Spanu A, Solinas P, Calia GM, Lovigu $C$, Chessa F, et al. Bone mass loss and vitamin D 
metabolism impairment in HIV patients receiving highly active antiretroviral therapy. Q J of Nucl Med Mol Imaging. 2004;48(1):39-48.

23. Baumgartner RN, Stauber PM, Koehler KM, Romero $L$, Garry PJ. Associations of fat and muscle masses with bone mineral in elderly men and women. Am J Clin Nutr. $1996 ; 63(3): 365-72$

24. Visser $M$, Kiel D, Langlois J, Hannan $M$, Felson D, Wilson $P_{,}$ et al. Muscle mass and fat mass in relation to bone mineral density in very old men and women: the Framingham Heart Study. Appl Radiat Isot. 1998;49(5-6):745-7.

25. Pluijm S, Visser M, Smit J, Popp-Snijders C, Roos J, Lips P. Determinants of bone mineral density in older men and women: body composition as mediator. J Bone Miner Res. 2001;16(11):2142-51.

26. Khosla S, Oursler MJ, Monroe DG. Estrogen and the skeleton. Trends Endocrinol Metab. 2012;23(11):576-81.

27. Bakker A, Klein-Nulend J, Tanck E, Albers G, Lips $P$, Burger $\mathrm{E}$. Additive effects of estrogen and mechanical stress on nitric oxide and prostaglandin E 2 production by bone cells from osteoporotic donors. Osteoporos Int 2005;16(8):983-9.

28. Nelson LR, Bulun SE. Estrogen production and action. J Am Acad Dermatol. 2001;45(3):S116-S24

29. VAN HEMERT AM, BIRKENHÄGER JC, DE JONG FH, VANDENBROUCKE JP, VALKENBURG HA. Sex hormone binding globulin in postmenopausal women: a predictor of osteoporosis superior to endogenous oestrogens. Clin Endocrinol. 1989;31(4):499-509.

30. Adami H-O, Johansson ED, Vegelius J, Victor A. Serum concentrations of estrone, androstenedione, testosterone and sex-hormone-binding globulin in postmenopausal women with breast cancer and in age-matched controls. Up J of Med Sci. 1979;84(3):259-74.

31. Shevroja E, Koromani F, Muka T, Oei L, Zillikens C, Hofman $A$, et al. Sex Hormone-Binding Globulin Is Associated With Markers Of Vertebral Fracture And Vertebral Fracture Risk. J Clin Densitom. 2018;21(4):1.

32. Chen $\mathrm{K}-\mathrm{Y}$, Wang $\mathrm{C}-\mathrm{H}$, Lin $\mathrm{T}-\mathrm{Y}$, Chang $\mathrm{C}-\mathrm{Y}$, Liu C-L, Hsiao $\mathrm{Y}-\mathrm{C}$, et al. Monitoring early developed low bone mineral density in HIV-infected patients by intact parathyroid hormone and circulating fibroblast growth factor 23. ] Microbiol Immunol Infect. 2019;52(5):693-9.

33. Kim MJ, Shim MS, Kim MK, Lee Y, Shin YG, Chung $\mathrm{CH}$, et al. Effect of chronic alcohol ingestion on bone mineral density in males without liver cirrhosis. Korean J Intern Med. 2003;18(3):174.

34. PERIS P, PARÉS A, GUANABENS N, PONS F, DE OSABA MJM, CABALLERIA J, et al. Reduced spinal and femoral bone mass and deranged bone mineral metabolism in chronic alcoholics. Alcohol Alcohol. 1992;27(6):619-25.

35. Ulhøi MP, Meldgaard K, Steiniche T, Odgaard A, Vesterby A. Chronic alcohol abuse leads to low bone mass with no general loss of bone structure or bone mechanical strength. J Forensic Sci. 2017;62(1):131-6.

36. Chakkalakal DA. Alcohol-induced bone loss and deficient bone repair. Alcohol Clin Exp Res. 2005;29(12):2077-90.

37. Paccou J, Viget N, Drumez E, Cortet B, Robineau O. Prevalence and risk factors for low bone mineral density in antiretroviral therapy-naive HIV-infected young men. Med Mal Infect. 2018;48(7):442-8.

38. Chaba DCdS, Soares LR, Pereira RM, Rutherford GW, Assone T, Takayama L, et al. Low bone mineral density among HIV-infected patients in Brazil. Rev Inst Med Trop São Paulo. 2017;59.

\section{Conflict of Interest}

The authors declare that they have no competing interests.

\section{Author contributions}

APS, BAA, DRLM and AMN conceived the study, participated in its design, coordination, and data acquisition. EBGG and ES participated in interpretation of the results and manuscripts drafts and final version. All authors contributed significantly, read and approved the final manuscript.

\section{Funding sources}

This study was financed in part by the Coordenação de Aperfeiçoamento de Pessoal de Nível Superior - Brasil (CAPES) - Finance Code 001 and the National Council for Scientific and Technological Development (CNPq, Brazil) grant number 141536/2016-0.

Corresponding author

André Pereira dos Santos

andreps@alumni.usp.br

Editor:

Prof. Dr Felipe Villela Gomes

Received in: May 11, 2020

Approved in: Nov 27, 2020 